\title{
技術展望。
}

\section{転圧コンクリート舗装の現状と課題 \\ STATUS REPORT ON ROLLER COMPACTED CONCRETE PAVEMENTS}

\author{
多田宏行* \\ By Hiroyuki TADA
}

\section{1. はじめに}

転圧コンクリート舗装 (Roller Compacted Concrete Pavement, 以下 RCCP という) 工法は，通常の舖装 用コンクリートよりも著しく水量を減じた超硬練りのコ ンクリートを，アスファルトフィニッシャなぼで路盤上 に敷きならし，これを振動ローラなどによる転圧で十分 に締め固めて, 高強度のコンクリート舗装版を得ようと するもので, 従来のセメントコンクリート舗装に比較し て工費の低減が期待できる，特殊な舗設機械を必要とせ ず施工速度が早い，早期に交通開放が可能であるなどの 特徵を備えている.

本工法が近年，世界的に関心をもたれだした契機は， (a) 第 1 次オイルショック（1973 年）によるアスファル トの不足と価格高騰に対応したコンクリート舗装の見直 し気運, (b)型振動ローラや高楴固め型のアスファルト フィニッシャの出現, (コンクリートダムの施工法とし ての RCD (Roller Compacted Dam) 工法の実績の増 大などであるが，直接的には®により信頼性のある施工 が可能になったことの影響が大きい.

海外における RCCP 工法の道路舗装への適用の実態 をみると，すでに試験的段階から実用的段階に達してい る国も少なくない，本工法を採用している国にはスペイ ン，フランス，ノルウェー，スウェーデン，アメリカ， カナダ，オーストラリアなどがあり，1986 年までの全 施工面積は 800 万 $\mathrm{m}^{2}$ を上回るものと推定される.

このように，RCCP 工法は世界的に普及しつつある

* 正会員 工博 (財) 日本道路交通情報センター副理事長 (社) 日本道路協会舗装委員会委員長

（テ102 千代田区九段南 1-6-17）

Keywords : roller compacted concrere pavement, no-slump concrete, compaction with vibratory roller, concrete mix design, white base
が，わが国においても近年，急速に関心が高まり，施工 実績の増加とともにそのデータの集積も進み, 本工法の 技術的検討も本格化してきた。

本文では，RCCP の位置づけと欧米における状況を 紹介するとともに，わが国の RCCP 工法の現状と今後 の展望について述べる.

\section{RCCP 工法の概念と特徵}

\section{（1） RCCP工法の概念}

コンクリートの品質に及ぼす単位水量と締固めの関係 は，図一1 $1^{11}$ のうな概念で示される.すなわち, RCCP 工法に用いるコンクリート (以下, RCC という) は, 強力な締固めエネルギーを用いれば単位水量の少な い高品質 (高強度, 高密度) な転圧コンクリート版（以 下 RCC 版という）が作り出せることに着目した工法と いえる.

また RCC は, 各種コンクリートの中では図一 $2^{2)}$ の ように位置づけられ，粗骨材が多く骨材のかみ合わせが 期待でき, かつ単位水量の少ない配合であることが特徵 である.このため, 転圧終了後の RCC 版の表面は, 施 工作業員が入っても, また散水養生用の車が乗り入れて

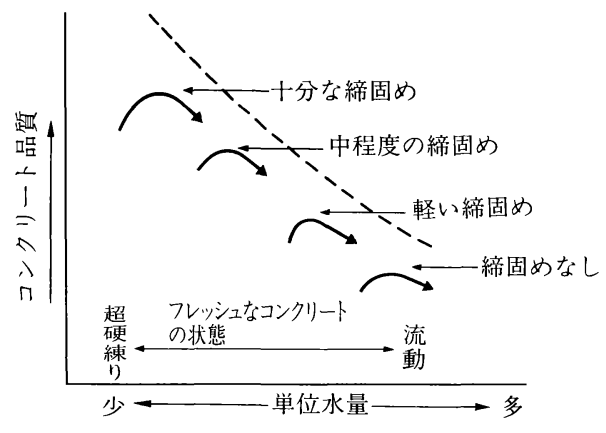

図一1 コンクリートの品質と単位水量, 締固めの概念” 


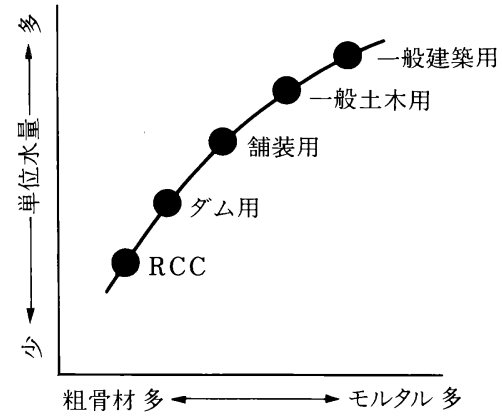

図一2 各種コンクリートの配合の概念 2 )

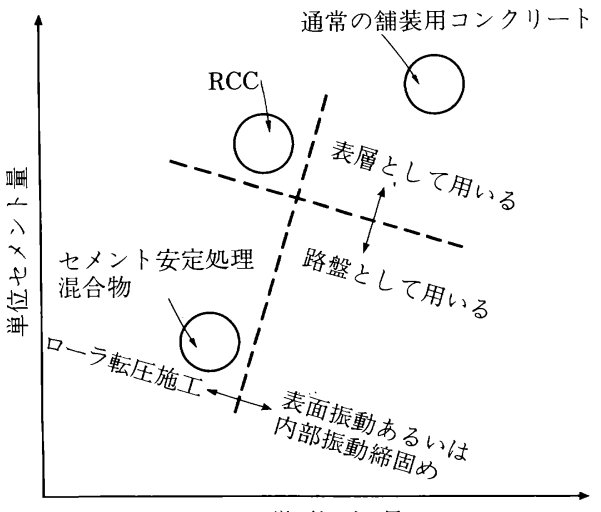

単 位 水量

図一3 舖装用セメント混合物における RCC の位置づけ3)

も，特に問題はないほどに安定している.

さらに，舗装用のセメント混合物の中では，図一 $3^{3)}$ のように, 単位水量の点からはセメント安定処理混合物 に近く, セメント量では通常の舗装用コンクリートに近 いといえよう.なお，図中では RCC は表層に用いると して位置づけられているが，路盤として RCC を用い， その上に表層を施工する舗装構造とすることもある.

これらを総合すれば，RCCP 工法はセメント安定処 理路盤工法と通常のコンクリート舗装工法の同一線上に あるものと考えられ，両工法との関係を端的に表現すれ ば表一1のようになる.

\section{（2）RCCP工法の特徴}

上述の特性より, RCCP 工法には従来のコンクリー 卜舗装と比較して次のような特徴が挙げられる.

(1) 単位水量およびセメント量が少なく, 乾燥収縮量 が小さいため, 走行性に影響を及ぼす目地の省略あるい は設置間隔を拡大することができる.

(2) 初期材令時の耐荷力に優れ，早期に交通開放がで きる.

(3) 特殊な専用機械を用いることなく, アスファルト 舗装用の舗設機械で施工できるため施工速度が早く，工 費の節減も期待できる.
表一1 RCCP とそのほかの工法の関係

\begin{tabular}{c|l|c|c}
\hline \multirow{2}{*}{ 特 性 } & $\begin{array}{c}\text { 通常のコンク } \\
\text { リト舗装 }\end{array}$ & $\begin{array}{l}\text { セメント安定 } \\
\text { 処理路盤 }\end{array}$ \\
\hline \multirow{2}{*}{ 配 合 } & 単位水量・含水比 & $\times$ & $\bigcirc$ \\
\cline { 2 - 4 } & セメント量 & $\bigcirc$ & $\times$ \\
\hline \multirow{2}{*}{ 施工 } & 施工性 & $\times$ & $\bigcirc$ \\
\cline { 2 - 4 } & 締固め & $\times$ & $\bigcirc$ \\
\hline \multirow{2}{*}{ 性 能 } & 強度・耐久性 & $\bigcirc$ & $\times$ \\
\cline { 2 - 4 } & 表層使用 & $\bigcirc$ & $\times$ \\
\hline
\end{tabular}

（注） $\bigcirc$ : 類似， $\times$ : 相異

(4) 型枠を用いない施工も可能のため, RCC 版厚は 自在に変えられる.

一方, RCCP 工法の一般的な課題としては次のよう な点が挙げられる.

(1) RCC 版施工時の平坦性や供用下における表面の きめの確保に，工夫と検討を要する.

(2) 収縮ひびわれに代表される発生ひびわれをコント ロールするか, しないか, つまりカッタによる切削目地 (以下, カッタ目地という) の設置を設計施工上の前提 とするか，しないかに検討の余地がある.

\section{RCCP 工法の技術開発の背景}

\section{（1）海外における現状}

前述のように, RCCP 工法には多くの利点があるが, 本工法の実用化の試みは欧米諸国の方が早く, その実績 も多い.たとえば 1986 年現在で施工実績の多い国を挙 げるとスペイン 430 万 $\mathrm{m}^{2}$, フランス 240 万 $\mathrm{m}^{2}$, カナダ 80 万 $\mathrm{m}^{2}$, アメリカ 40 万 $\mathrm{m}^{2}$ の順となっている.

ところで著者は, (社) セメント協会の企画により 1987 年, 1988 年の 2 回にわたって海外の RCCP の実 状を現地調査する機会を得た.この現地調査による知見 と入手資料の検討のほか, 各種の文献調査の結果から結 論を要約すると，およそ次のようである ${ }^{4)}$.

(1) RCCP の道路への適用は, スペインが最も古く, 1970 年代初期に遡ることができ, 1980 年代中期には軽 交通道路から重交通道路へと適用範囲を拡大しはじめ た.

(2) 各国とも第一次オイルショック（1973 年）を契 機としてRCCP に対する関心が高まり, その研究も促 進されて，1970 年代中期から実績が増大した。

1980 年代中期には, 重車両が低速走行するヤードな どにおける試験施工の時代を脱して, RCCP の技術的, 経済的な優位性の評価も定まり, 一般道路への適用の段 階に達している.

(3) RCCP 採用の主な理由は, (a急速施工, (b)早期 供用可能, (C)経済性にある. 一方, 主な問題点としては, (a)収縮クラックの発生をコントロールすることについて 検討の余地があること, (b平坦性の確保に留意を要する 
ことが挙げられる. しかし, これらの問題点についても 解決の努力が続けられており, RCCP は今後とも普及 の傾向にある.

(4) 各国の研究成果と実績に照らして判断すると, RCCP のわが国の道路への導入は，国情の相違による 課題はあるものの, 有望であると思われる.

\section{（2）わが国における関連技術}

わが国の RCCP の開発研究は 1987 年に本格化して から急速に進展したが，この背景にはわが国独自の技術 的蓄積があったことも見逃せない。ここで参考までに， 今日の RCCP 開発に関連したセメント混合物による転 圧タイプの施工技術について概観しておく.

a) 札幌千歳道路の $\mathrm{RCCP}^{5}$

わが国最初の大規模な RCCP の施工例は，1952 1953 年に札幌干歳道路の千歳寄り延長 $7027 \mathrm{~m}$ に実施 されたものである. 舗装断面は，図一 4 に示すように 18 $\mathrm{cm}$ 厚の RCC 版をホワイトベースとし，その上にアス ファルト混合物 $5 \mathrm{~cm}$ を施工する, 今日でいうところの コンポジット舗装に相当するものであった.

施工は，トラックで運搬された混合物を人力で荷おろ しし，敷きならし， $6 \mathrm{t}$ 以上のローラで転圧するもので あったが，工事の仕様は基本的には今日のものと異なら ず，施工機械を置き換えればそのまま現在でも通用し得 るほどである。

b）セメント安定処理路盤工法

この工法は, わが国でも古くから行われており，その 技術的基準も 1961 年にはアスファルト舗装要綱（日本 道路協会）に定められている. わが国のセメント安定処 理混合物はセメント量 2 4\%（ちなみに，RCC のそれ を同一表示で示すと $10 \%$ 前後）のもので，材令 7 日で の一軸圧縮強度は $20 \sim 30 \mathrm{kgf} / \mathrm{cm}^{2}$ 程度, 施工厚は 15 $30 \mathrm{~cm}$ である.

施工には，混合物の敷きならしにベースペーバ，締固 めに振動ローラやタイヤローラなどの機械が用いられ， 転圧終了後ただちにアスファルト乳剂を散布して, 乾燥 収縮を防ぎ，養生するのが一般的である。
本工法は多くの施工経験から十分に耐久性があること が実証されている，したがって，ほぼ同様な機械で施工 する RCCPには，このセメント安定処理路盤に関する 技術の応用の範囲が広い.

c）セメントマカダミックス工法

この工法はマカダム工法の一種で, 単粒度骨材 （60/40 や 40/20 mm）を水・セメント比 $40 \%$ 程度の細 砂使用モルタルで混合被覆し，これを敷きならし，ロー ラで締め固めるギャップ粒度の転圧コンクリートであ る.

粒ぞろいの粗骨材のかみ合わせとセメントペーストの 結合力とを期待する工法で, 一般には舗装の路盤に適用 するが，全国的に普及するには至らなかった。

d) RCD (Roller Compacted Dam) 工法

わが国の RCD 工法の実施は, 急速施工性, 経済性な どに着目して 1974 年より始まり, 現在ではその技術も ほぼ確立されたものになっている。

RCD コンクリートは, RCCP 工法の混合物に比べ, 当然のことながら粗骨材の最大寸法が大きく，またコン クリートの発熱抑制を重要視することから単位セメント 量は $120 \sim 130 \mathrm{~kg} / \mathrm{m}^{3}$ 程度と少ないなどの違いがある.

これら技術の開発過程で得られた転圧コンクリートの ノウハウを RCCP 工法に活用しようとするのが， RCD 工法からの RCCP 開発研究へのアプローチである.

\section{4. わが国の RCCP の現状}

\section{（1）調查・研究の態勢}

わが国の RCCP は建設省, 日本道路公団などをはじ め民間でも実施されているが，これらの施工結果を踏ま えての技術的検討は，行政機関のほか（社）日本道路協 会, (社) セメント協会, (社) 日本道路建設業協会など にそれぞれ設置されている RCCP に関連する委員会に おいて，おのおのの分担分野に応じて進められている.

すなわち，セメント協会は建設省関東地方建設局と共 同で，その技術開発を 1987 1989 年度の 3 か年計画で 実施中で，目地間隔の拡大を図るための低収縮セメント

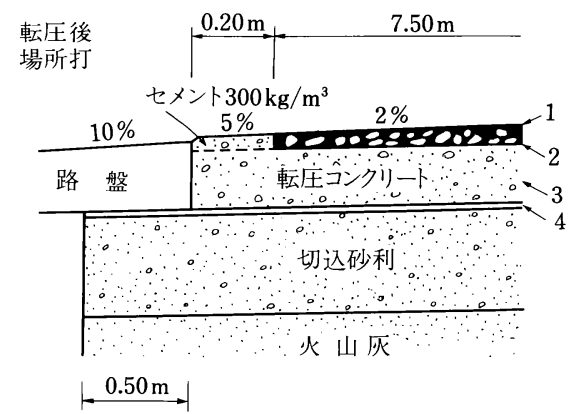
1. 細粒式アスコン $5 \mathrm{~cm}$ アスファルト $9 \%$ 石 粉 6 砕 石 25 砂 60

2. プライマー アスファルト乳剂 $1 \mathrm{l} / \mathrm{m}^{2}$

3. 転圧コンクリート $18 \mathrm{~cm}$

$\begin{array}{ll}\text { セメント } & 210 \mathrm{~kg} / \mathrm{m}^{3} \\ \text { 砂 利 } & 10 \mathrm{~m}^{3} \\ \text { 砂 } & 0.4 \mathrm{~m}^{3} \\ \text { 敷 砂 } & 1 \mathrm{~cm}\end{array}$

図一4 札幌千歳道路 RCCP の埔装断面 ${ }^{5}$ 
を開発するなどの成果をおさめつつある.

また，1988 年 8 月には，日本道路協会の舗装委員会 は RCCP の設計・施工の効率的な調査研究に資するた め「転圧コンクリート埔装試験施工要領」6) (以下, 施 工要領という）を作成した。これに基づいて全国的な規 模で試験施工が行われ，またこの施工要領は民間で実施 される工事のガイドラインとしても役立っている。

一方, 日本道路建設業協会は 1988 年 4 月に RCCP 部会を発足させ，主として施工面からみた問題点の整理 を急いでいる.

ところで，次節に述べるように施工実績の急増と関係 機関の協力が幸いして，全国各地で官民の試験施工で得 られるデータの集積も順調である.日本道路協会におい ては，これらを総合的に整理検討のうえ，わが国の実情 に対応した RCCP の技術基準を策定する計画である.

\section{（2）わが国の RCCPの現状}

海外における.RCCP の普及傾向に刺激されて, 1987 年 2 月にセメント協会が大阪のセメント工場構内で実施 した公開試験舗装工事は，官民関係者の強い関心を集め たが，この年の秋から堰を切ったように各地で試験施工 が行われるようになった，札幌千歳道路での施工からみ れば実に 35 年ぶりのことである.

わが国の RCCP の近年 (1987 年以後) の施工実績 ${ }^{7)}$ は北海道, 東北, 関東, 北陸, 中部, 近畿, 中国, 四国 および九州において件数で約 50 件，延面積で約 13 万 $\mathrm{m}^{2}$ となっている. 目下のところ RCCP の技術開発は， 官民一体となって促進する気運にあり，これらの施工の 大半が公開試験の形をとっている.

以下に，これらの実績に基づきながら，わが国の RCCP の現状を述べてゆきたい。

a) 適用箇所

RCCP の施工実績 49 件を適用箇所で区分してみる と, 図一5 のようである. 図によれば構内道路やヤード などへの適用が比較的多い。これは当初の技術開発が-
般道路への適用に先立って,まずこれらによって施工性， 供用性を確認しようと意図したところが多いためであ る.また，型枠を用いなくても施工でき，早期交通開放 が可能でもある RCCP が，複数レーンにわたって施工 することの多い構内やヤードなどに適用しやすいという 現実的な背景もあったと推察される。

一方，一般道路における適用については，建設省の各 地方建設局における技術活用パイロット事業などとして 進められているほか，1988 年度には L 交通〜 B 交通の 一般道路への適用性を検討するため, 前節で述べた施工 要領に基づいて全国 6 か所 7 件の試験舗装が国の補助事 業で実施された。

今後，これらの施工データおよび供用データを体系的 に取りまとめて，技術基準作成にフィードバックさせて ゆくことになっている。

b ) 舗装構造

1) RCC 版厚の設計

施工箇所の RCC 版厚の分布は図一6に示すとおり で，版厚が $25 \mathrm{~cm}$ までのものが圧倒的に多い.

セメントコンクリート舗装要綱 (日本道路協会) では, 通常のコンクリート舗装の版厚を $15 \mathrm{~cm}$ ( $\mathrm{L}$ 交通), 20 $\mathrm{cm}$ (A 交通)，25 cm (B 交通)，28 cm ( $\mathrm{C}$ 交通)，30 $\mathrm{cm}$ (D 交通)のように交通量に対応して規定しているが, RCCP の版厚も当面はそれに準じている。

ただし，RCCPにおける路盤の支持力については交 通量の区分にかかわらず $K_{30} \geqq 20 \mathrm{kgf} / \mathrm{cm}^{3}$ としている.

$25 \mathrm{~cm}$ 以下の RCC 版厚を通常のコンクリート舗装版 厚之同一に扱っているのは, 硬化後の RCC 版の力学的 挙動が基本的には通常のコンクリート舗装と同一である こと, 版厚設計の決め手となる RCC の曲げ強度や疲労 性状が舗装用コンクリートとほぼ同程度とみなせるこ と年, 9) などを, 現在のところその根拠としている.

なお，版厚 $25 \mathrm{~cm}$ を超える RCCP の適用性について は，5．で述べるように基本的に検討すべき部分がなお

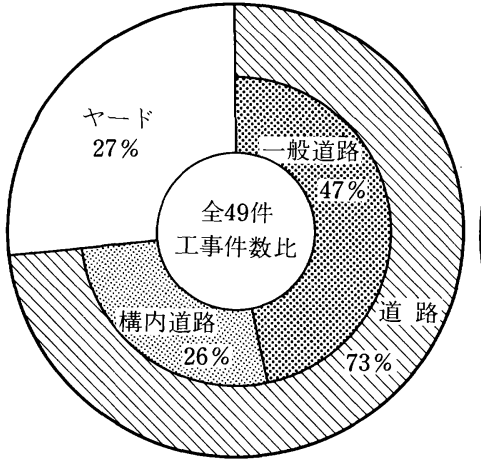

(a) 工 事 件 数 比

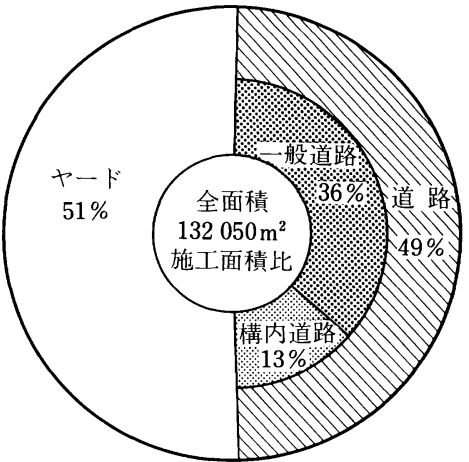

（b）施 工面積比

図一5 RCCP の適用箇所 (1989 年 7 月現在, セメント協会調ベ)

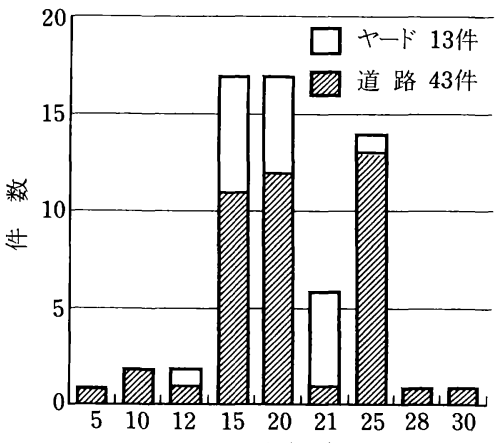

版 厚 $(\mathrm{cm})$ 
残されているが，現在いくつかの試験施工計画が進めら れている.

\section{2）目地の構造・間隔}

わが国の通常のコンクリート舗装版の構造は, 目地部 にスリップバー，タイバーを用いて荷重伝達をはかり， また版内に鉄網を敷設して，発生するひびわれの拡大を 抑制している.

しかしながら RCC 版の場合，これらの補強材を版内 に設置することは，一部で試験的に試みたものの，施工 がきわめて困難であり，信頼性のある補強とはなりにく いので，これらの補強は行わない.

次にコンクリート版には，ある間隔で収縮ひびわれが 必ず発生するが，これをカッ夕目地により所定位置に誘 導するか, しないか, 誘導するとすればどの程度の間隔 でカッタ目地を設けるかなどが課題となる.

わが国の場合，現在のところ収縮ひびわれなどをカッ 夕目地で誘導する方法を一般にとっている.したがって，
試験施工のかなりの箇所で目地間隔を種々変えた検討を 実施している。

これまでに発表されたデータから，目地を全く設けな い場合の発生ひびわれ間隔を推察すると，およそ版厚 $15 \mathrm{~cm}$ で $15 \mathrm{~m}$ 程度，版厚 $20 \mathrm{~cm}$ で $15 \sim 20 \mathrm{~m}$, 版厚 25 $\mathrm{cm}$ で $25 \mathrm{~m}$ 程度であり, 目地間隔は通常のコンクリー 卜舗装の目地間隔（8～10 m) よりも大きくできること が，ほぼ確認されてきた。

c ）配合設計

1) 配合設計法

RCC の配合設計は，これまでの調查研究に基づき， 図一7 のような手順で行っている.すなわち， RCC と しての適切なコンシステンシーとなる最適含水比あるい は最適単位水量を求め, 次にこの水量でセメント量を変 化させた曲げ強度試験用供試体 $(10 \times 10 \times 40 \mathrm{~cm})$ を作 り, 配合曲げ強度（材令 28 日）を満足するセメント量 を求めるものである.

表一2ＲCCのコンシステンシー評価法

(a) 振動台による評価法

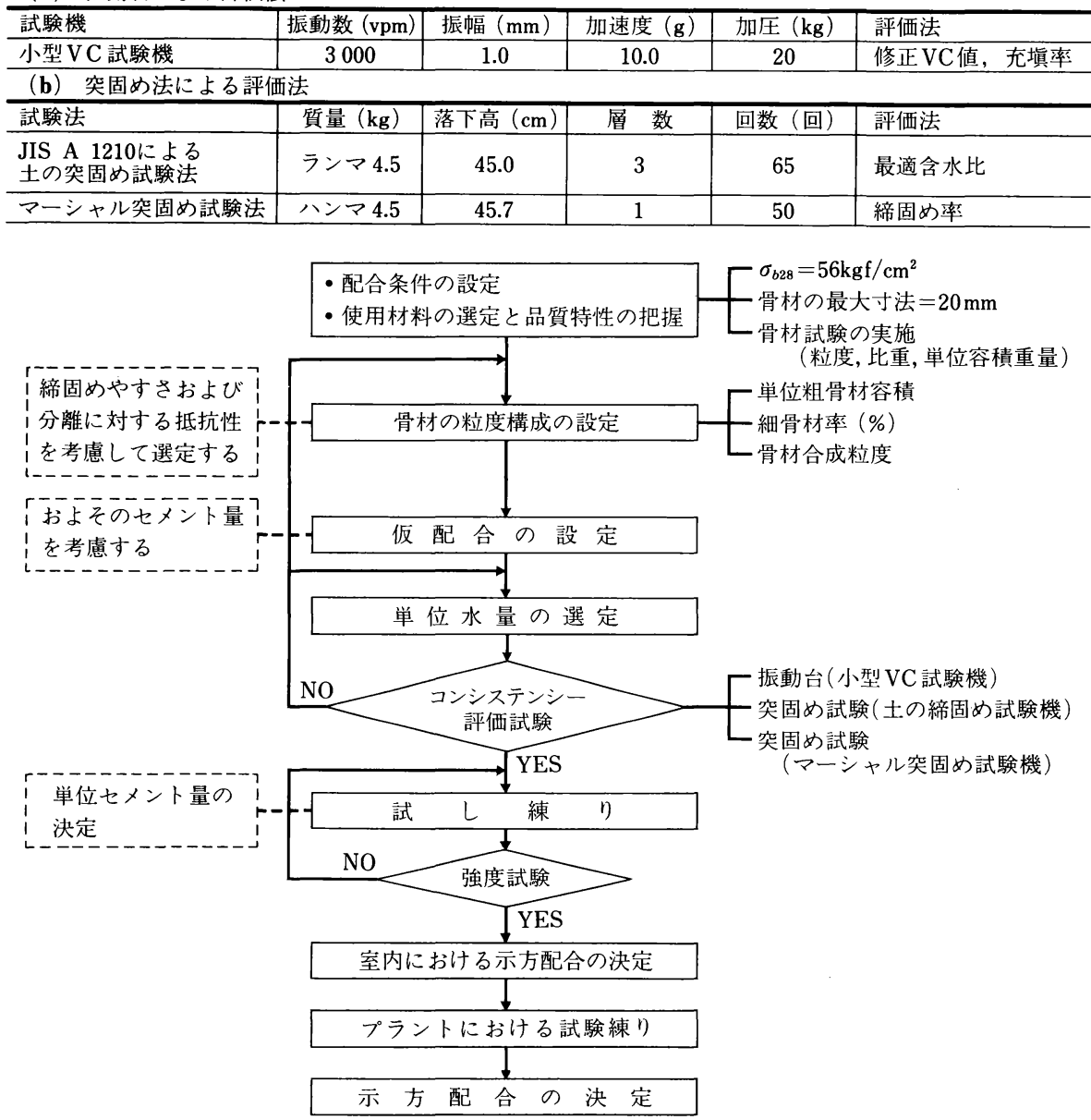

図一7 RCC の配合設計フロー 
コンシステンシーの評価は, 表一 2 に示す 3 種の試験 法のいずれかで行われているが, 精度や作業の容易性な どから，いずれ統一されることになろう.

曲げ強度試験結果の例を示すと, 図一 ${ }^{10)}$ のようであ る. 図一8（b）は日本道路公団が主に用いている整理 方法で, セメント水比 $(C / W)$ のほかに曲げ強度試験 用供試体の空隙率 $(A)$ も考慮した $C /(W+A)$ を用い る点が注目される.

なお， RCC 版の設計基準曲げ強度としては，通常の コンクリート舗装版と同じ材令 28 日の曲げ強度 45 $\mathrm{kgf} / \mathrm{cm}^{2}$ を採用する. 配合設計で用いる配合曲げ強度は, RCC の製造および施工上の変動に関してまだ十分な データが蓄積されていないことを考慮して，現在のとこ ろ $56 \mathrm{kgf} / \mathrm{cm}^{2}$ (施工要領) あるいは $60 \mathrm{kgf} / \mathrm{cm}^{2}$ （日本 道路公団）の通常の舗装用コンクリートの配合強度 52 $\mathrm{kgf} / \mathrm{cm}^{2}$ より割増し係数を高めにとっている。

2） RCC の配合

通常の舗装用コンクリートにおける粗骨材の最大寸法 は $40 \mathrm{~mm}$ が標準であるが，RCC の場合には均等質な版 の形成と良好な施工性を得るため, 最大寸法 $20 \sim 25$ $\mathrm{mm}$ のものが大半を占める.

RCC の単位水量の分布は図一 9 に示すとおりで, 通 常の舗装用コンクリートが $120 \sim 140 \mathrm{~kg} / \mathrm{m}^{3}$ 程度である のに比較して, 単位水量は $30 \mathrm{~kg} / \mathrm{m}^{3}$ 程度少ない.

単位セメント量の分布は図一10に示すとおりである. 通常の舗装用コンクリートの単位セメント量が 300

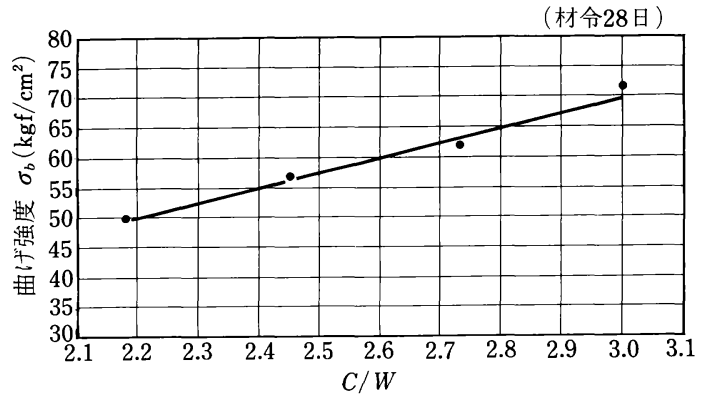

（a）セメント水比 - 曲げ強度の関係

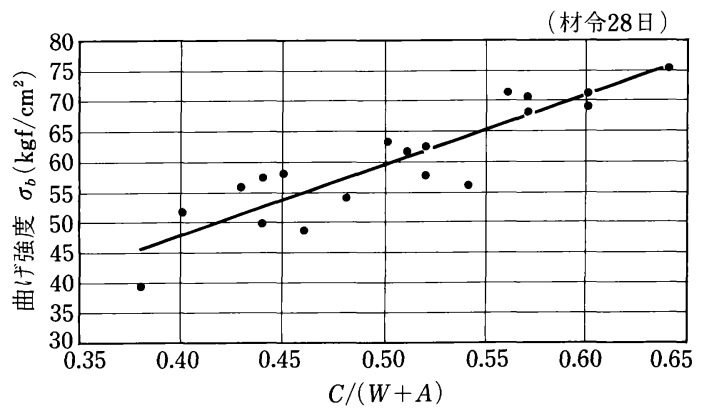

(b) セメント空隙比一曲げ強度の関係

図一8 RCC の曲(゙強度試験結果例 ${ }^{10)}$ $\mathrm{kg} / \mathrm{m}^{3}$ を越える場合が多い実態からすれば，RCCP は $20 \mathrm{~kg} / \mathrm{m}^{3}$ 以上減らしたものを施工している.

なお，混和剤については大半が使用しており，その夕 イプは $\mathrm{AE}$ 減水剤標準型か遅延型が多い.

また, 細骨材率 $(s / a)$ と単位粗骨材量の分布を示すと, それぞれ図一11 と図一12のようになる，s/a は広範囲 に分布しているが，これは RCC 版を表層として施工し た例がほとんどで，版の十分な締固めのほかに，路面の

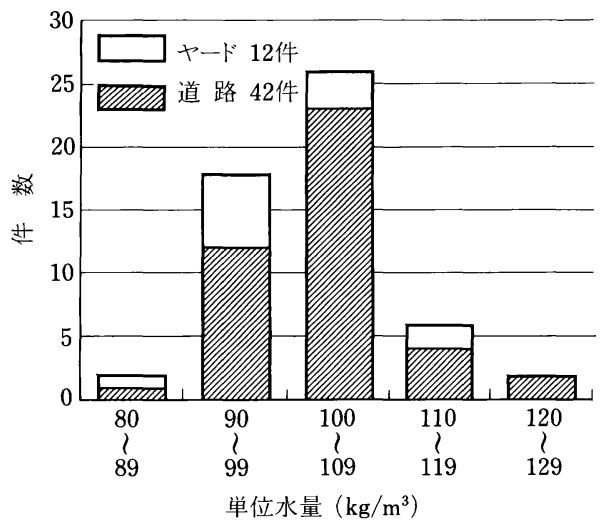

図一9 RCC の単位水量の分布

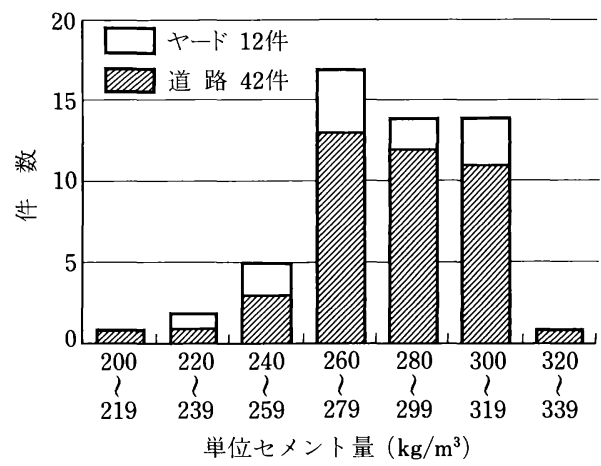

図一10 RCCの単位セメント量の分布

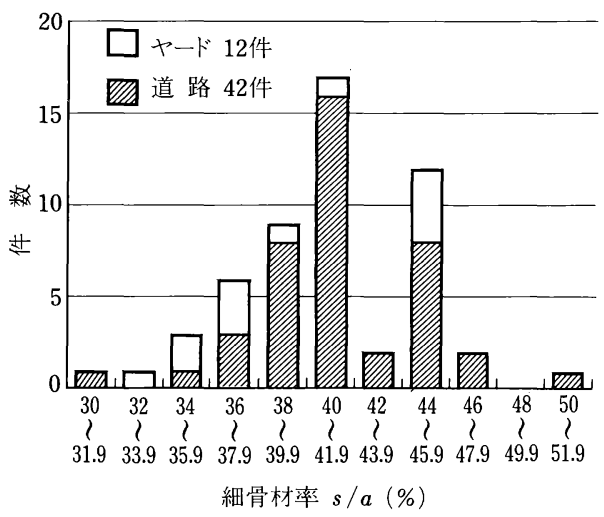

図一11 RCC の細骨材率 $(s / a)$ の分布 


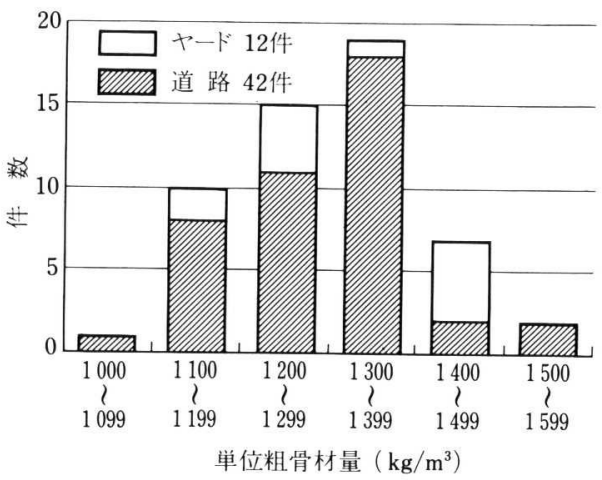

図一12 RCC の単位粗骨材量の分布

ち密性，材料分離が生じにくい配合などを模索している 結果とも考えられる。一方, 単位粗骨材量は通常の舗装 用コンクリートが $1100 \mathrm{~kg} / \mathrm{m}^{3}$ 程度であるのに対して, これより $100 \sim 200 \mathrm{~kg} / \mathrm{m}^{3}$ 程度多い.

以上をまとめると,わが国の RCC の配合は通常の舗 装用コンクリートに比較し, 単位水量, 単位セメント量 を減らし, 骨材全体の量を增加させており, 一方, 細骨 材率については什上げ・分離あるいは版底面部の密度の 確保などに対する配虑からか，30～51\%というかなり 広い範囲で試みられている.

d) 施 工

$\mathrm{RCCP}$ の施工のフローを例示すると図一13 のとおり で, 舖設状況を示すと写真一1のようである.

1） RCC の練りまぜ，運搬

RCC の練りまぜは，ほとんどが既存の生コン工場で 行われている. 超硬練りコンクリートであるので強制練 りミキサを用いる場合が多く,また練りまぜ量もミキサ の公称能力の $2 / 3$ 程度とすることが多い．施工現場への 運搬はダンプトラックによる.

練りまぜにかかわる重要な管理点は RCC の単位水量 である，RCCのコンシステンシーの変動が施工に及ぼ す影響はきわめて大きく, 単位水量が過剩な場合はロー ラ転圧時に RCC は波をうち, 所要の平坦性が得られな

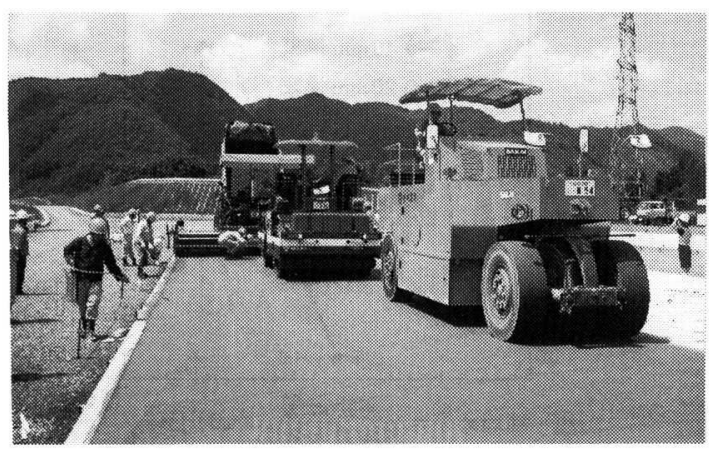

写真一1 RCCP の赤設機械編成例

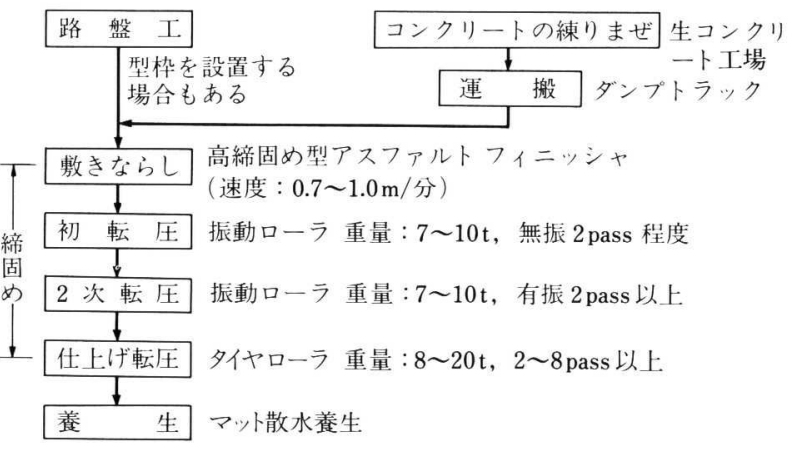

図一13 RCCP の施エフロー

い. 一方, 過少の単位水量の場合には, 十分な楴固め密 度が得られず, 分離も生じやすい.

したがって, 単位水量（特に細骨材の表面水）の厳密 な管理が重要である.また運搬時には必ずシートで覆い, RCCの乾燥を防ぐ必要がある.

なお，RCCの練りまぜから締固め終了までの許容時 間は,施工時期により異なるが,一般に 60〜90 分である.

2) 敷きならし

$\mathrm{RCC}$ の敷きならしは, 厚層 $(15 \sim 30 \mathrm{~cm})$ の混合物 を一層で敷きならすので, 材料分離を起こさず, 均一な 密度で平坦に敷きならせるアスファルトフィニッシャを 用いる. しかも道路舗装に要求される出来形（平坦性な ど）を満足させるためには, 敷きならし時点で相当程度 の締固め度を得ていないと, その後の転圧時の不陸の発 生を防ぎにくいので, 強力な締固め機構を備えたアス ファルトフィニッシャを使用することが多い.

3) 転 圧

版の底面部まで十分に締め固めるため, 自重 7 10 t の振動ローラを用いて転圧している. 振動ローラによる 転圧方法は, セメント安定処理路盤の場合と基本的には 同じであるが, 一般に初転圧は無振で 2 pass 程度, 2 次 転圧は有振で 2 4 pass 程度としている.

振動ローラの転圧後には, 什上げ転圧としてタイヤ ローラ 8〜 20 t を用いて, 表面部をよりち密化するとと もに，供用の初期に生ずることのある表面部モルタルの 剥脱や飛散を招かないようにする.

なお，転圧時にヘアクラックが生じやすい場合，これ の消去のため, 仕上げ転圧に水平振動式ローラを併用す ることもある

\section{4) 養生}

$\mathrm{RCC}$ 版の最も一般的な養生方法は, 通常のコンク リート舗装版と同様に養生マットを用いた 3 日散水養生 である・

RCC 版が早期に交通開放できる特徴は, その修繕工 事への適用の場合には特に重要であり，一部では 1 日散 
水養生で交通開放することも試みられたが，表面のきめ 保持の面でなお検討を要するようである.

これらの点から最近の施工では， RCC 版用の被膜養 生剤の試用や，ポリマーセメントミルクあるいはモルタ ルによる表面処理で，早期開放性と表面強化の改善を図 ろうとする試みも行われている.

\section{5. 今後の課題と展望}

最近の RCCP の施工実績は件数が急増するととも に，その施工規模もしだいに拡大し，累積施工面積は今 年度中に 30 万 $\mathrm{m}^{2}$ に達すると予想されている。

このように RCCP の適用可能性が広範囲に調査され るにつれて，有用な技術情報が着々と集積されるように なったので，わが国の RCCP 工法の舗装工法における 地位と技術基準の確立も, そう遠くないと思われる.

以下では，現時点でみた RCCP 工法の主要な課題よ 展望について述べる.

\section{（1）RCCP工法の主要な課題}

a) 舗装構造

1） RCC の硬化後の力学的挙動は, 通常のコンク リートとほぼ変わらないことから, 従来の設計法の適用 は可能であろう。しかし現時点では長期の供用デー夕が 得られていないことから, 今後, 蓄積されるデー夕に基 づいて検討を加えていかねばならない.

また，RCCP の優れた特徵を積極的に活かしていく ためには，既存のコンクリート舗装と同一の舗装構造を 考えるばかりでなく，たとえばセメント安定処理路盤と 組み合わせた複合版とする考え方，あるいは表層として セメント系あるいはアスファルト系の材料で被覆するコ ンポジット舗装の考え方を採り入れるなど，柔軟な対応 が必要である.

2）わが国では，収縮ひびわれを所定の位置に誘導す るためにカッ夕目地による収縮目地（版厚の約 $1 / 4$ を切 削）を設けている.

しかし諸外国においては，カッタ目地を設けない国の 方が多い. その理由としては，RCC 版に発生するひび われはその開き幅が狭く，ひびわれ面でのかみ合わせに よる荷重伝達が期待できる, またカッ夕目地を設けると すれば，かなり早期にカッタを入れる必要があるため， 切削面の乱れを生じやすいので好ましくないなどとして いる.

わが国の場合は実施工段階に入って年数も浅いので, これら収縮目地の供用性や効果についてはまだ明らかで なく, 発生ひびわれ間隔やひびわれ部の挙動の調査が必 要である.

RCCP の目地間隔は，RCCP のひびわれ発生に対す る評価・認識によって異なってくる，収縮目地の必要性
は，RCCP の用途，舗装構造などによって，使い分け られるようになろう.

3） RCCP を C，D 交通量区分の重交通道路へ適用 する場合には， RCC 版厚を厚くするか，あるいは一定 限度に抑えるかの 2 つの方法が考えられる.

i）セメントコンクリート舗装要綱に準拠すれば $\mathrm{RCC}$ 版厚は $28 \mathrm{~cm}, 30 \mathrm{~cm}$ となる，また，空港エプロ ン舗装への適用を想定すれば $30 \mathrm{~cm}$ 以上となることも 多い。このように厚い RCC 版を 1 層で敷きならして転 圧する場合は，特に版下層部の締固め密度の確保に留意 する必要がある。

すなわち，転圧による締固めエネルギーは RCC 版内 で深さ方向に減衰するので, 締固め密度も図一1 $4^{111}$ に 例示するように一般に低下する，一方， RCC の曲げ強 度は図一8で示したようにセメント水比 $(C / W)$ のほ かに空隙率の大小によっても影響され，空隙率が大きい ほど曲げ強度は小さくなる。

したがって，RCC 版厚が厚くなるほどこの点に関す る構造設計，施工面での検討が重要となってくる．

なお，海外においては厚さ $25 \mathrm{~cm}$ を超える RCC 版は 2 層敷きならし, 1 層転圧あるいは 2 層転圧で施工して いる例がみられるが，上下層間境界の付着の一体性の問 題があるとしている.

ii ） RCC 版厚の限界を $25 \mathrm{~cm}$ と考えた場合には, 表一3に示す検討が考えられる。

(1) 版厚は $25 \mathrm{~cm}$ を上限として, 設計基準曲げ強度 $45 \mathrm{kgf} / \mathrm{cm}^{2}$ を増すことによって対処する考え方で，比 較的容易に対応できる. 設計基準曲げ強度としては版厚 $25 \mathrm{~cm}$ とした場合, 試算によれば C 交通で $50 \mathrm{kgf} / \mathrm{cm}^{2}$ 程度, D 交通で $52 \mathrm{kgf} / \mathrm{cm}^{2}$ 程度にする必要がある.

(2) 路盤の強化によって対処する方法で，路盤にはセ メント安定処理路盤あるいは貧配合の RCCP の利用が 想定される.

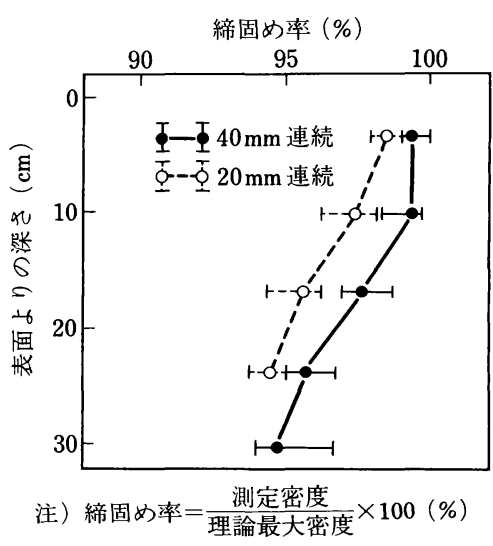

図一14 深さ方向の締固め密度の測定例 ${ }^{11)}$ 
表一3 RCCP の赤装構造の検討点

\begin{tabular}{l|c|c|c}
\hline \multirow{2}{*}{ 検討事項 } & (1) & (2) & (3) \\
\cline { 2 - 4 } & $\begin{array}{l}\text { 設計基準 } \\
\text { 曲げ強度 } \\
\text { の增加 }\end{array}$ & $\begin{array}{l}\text { 路盤の } \\
\text { 強化 }\end{array}$ & $\begin{array}{l}\text { RCC版を } \\
\text { ホワイトへ } \\
\text { ースとする }\end{array}$ \\
\hline R C C 版下面の耐荷力 & $\bigcirc$ & $\bigcirc$ & $\bigcirc$ \\
\hline 平坦性 & $\triangle$ & $\triangle$ & $\bigcirc$ \\
\hline 表面のち密性, 耐久性 & $\triangle$ & & $\triangle$ \\
\hline
\end{tabular}

(注） $\bigcirc$ : 直接的な効果, $\triangle: 2$ 次的な効果

\begin{tabular}{|c|}
\hline コンクリート版 \\
\hline 安定処理路盤 \\
\hline 粒 状 路盤 \\
\hline 路 \\
\hline
\end{tabular}

(舗装構造)

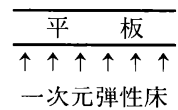

（舗装要綱の考之方）（複合平板理論）
図一15構造解析の考え方

路盤強化の評価方法としては@セメントコンクリート 舗装要綱に示される設計公式を適用し, 路盤の支持力 $K_{30}$ の増大によって評価する方法と, (b)図一15に示す複 合平板の理論 ${ }^{22}$ （福田氏）により評価する方法が考えら れる.

試算によれば RCC 版厚を $25 \mathrm{~cm}$ とした場合，(a)では 路盤の $K_{30}$ 值をC 交通で $60 \mathrm{kgf} / \mathrm{cm}^{3}$ 程度, D 交通で 100 $\mathrm{kgf} / \mathrm{cm}^{3}$ 程度にまで上げる必要がある.一方, (bでは $K_{30}$ 值が $7 \mathrm{kgf} / \mathrm{cm}^{3}$ 程度の路床上にセメント安定処理路 盤を $20 \mathrm{~cm}$ または $25 \mathrm{~cm}$ 設ければ， RCC 版下面に生ず る輪荷重応力を, $K_{30}$ 值が $20 \mathrm{kgf} / \mathrm{cm}^{3}$ 程度の路盤上に $28 \mathrm{~cm}$ または $30 \mathrm{~cm}$ の通常のコンクリート舗装版を施工 した場合とほぼ同等の応力にすることができる.

(3) 版厚 $25 \mathrm{~cm}$ の RCC 版上に, 表層として $5 \sim 10$ $\mathrm{cm}$ 程度のアスファルトコンクリートをオーバーレイを する方法である.

構造的な評価としては, アスファルトコンクリート表 層による輪荷重の分散効果と温度応力の低減などが考え られる. 多層弾性解析による試算では, $5 \mathrm{~cm}$ 厚のオー バーレイでは約 $10 \%, 10 \mathrm{~cm}$ 厚のオーバーレイでは約 $20 \%$ ほど RCC 版下面の輪荷重応力が軽減されるとい う結果もある.

これに RCC 版に発生する温度応力の低減が加わるこ とになるが, 表面温度 (上下の温度差) が $1{ }^{\circ} \mathrm{C}$ 低下す るごとに温度応力は約 $1 \mathrm{kgf} / \mathrm{cm}^{2}$ 程度軽减することか ら, 重交通道路用には $25 \mathrm{~cm}$ 厚の RCC 版をホワイト ベースに適用する構造は相当に有利と考えられる.

\section{b ）配合}

$\mathrm{RCC}$ の特徵を活かし, より広範囲への適用を考えた 場合は, 施工時の締固めエネルギーに対応した最適コン システンシーの評価方法あるいは適切な骨材粒度範囲の 設定など, 配合面での一層の検討が必要になってくる.

たとえば RCC 自体の施工性は現段階では必ずしもよ
いとはいえないが, これは単位水量, 単位セメント量を 極力減じようとする傾向に関係しているようである. し かしながら, 収縮ひびわれをカッ夕目地により所定位置 に誘導する方法をとる場合には, 少なくともこれらを限 界まで減ずる必要はないはずであって, RCC の適用方 法に応じて,その配合が定まっていくものと考えられる.

なお, RCC の施工性の改善の面では, RCC の可使 時間をより長くできる遅延型混和剤の開発や，フライ アッシュなどの混和材の使用の検討も望まれる.

c) 出 来 形

1） 日本道路協会の指導で実施した 7 件の試験舗装の データによれば, $3 \mathrm{~m}$ プロフィルメータによる平坦性 $\sigma$ は厚 $25 \mathrm{~cm}$ 版で $2.4 \sim 3.0 \mathrm{~mm}, 20 \mathrm{~cm}$ 版で $1.4 \sim 2.9$ $\mathrm{mm}, 15 \mathrm{~cm}$ 版で 1.4 1.6 mm である. 通常のコンクリー 卜舗装のそれは $2.0 \mathrm{~mm}$ 以下であるから, RCCP の平 坦性は現在のところ必ずしも満足すべき水準にはない. しかしこれは, 試験段階のものであり, 施工延長が短い ことも原因と考えられる.

平坦性の確保のために, RCC のコンシステンシーの 安定化のほかに, フィニッシャを停止させない連続施工 が前提となるので, 施工機械の能力に見合うコンクリー トの供給も重要な課題となる.

2） RCC は骨材が多いことと, 超硬練りであること から, フィニッシャでの敷きならし時に, 表面および底 面の一部で材料分離を生ずることがある. 表面部分の分 離は交通供用による剝脱,飛散につながる可能性があり， 底面部の分離は構造的耐荷力の低下を招くおそれがあ る.

したがって, 分離抵抗性からみた配合面での検討のほ か, フィニッシャ敷きならし時の分離防止策, 機械の改 善などの工夫も必要である.

特に舗装表面の仕上がりを重視する場合には, セメン トスラリー系またはモルタル系の材料を用いた表面仕上 げ方法の併用も考慮するとよい.

3）現在の一般的な養生方法は, 養生マットを用いた 少なくとも 1 3 日の散水養生が一般的であるが, 早期 交通開放の点では養生マットを使用しない養生方法の検 討も重要課題であり, 被膜養生あるいは表面処理を兼ね た RCC 表面の強化材料などの開発が望まれる.

\section{(2) 今後の展望}

わが国の舗装は, 1960 年前後までコンクリート舗装 が主要な地位にあったが, その後急激にアスファルト舗 装にとって替わられた．ところが今や膨大なストックと なったアスファルト舗装も, 重車両の走行による塑性流 動やスパイクタイヤなどの摩耗によるわだち掘れに代表 される破損が深刻な問題となっている.

このため耐久性に優れているコンクリート舗装を見直 
す気運がみられるものの, その施工機械が大がかりで, また施工後交通開放までの養生期間が長いなどの問題点 は相変わらず残されたままである.

このような背景にあって RCCP 工法は，これまでの 舗装が抱える課題に対する解決の可能性をもつ工法とし て注目されてきた。

すでに述べたように，わが国の RCCP 工法の開発は 着実な施工実績の積み上げに支えられ，基本的な検証は ほぼ終了しつつあり，日本道路協会では当面の技術的標 準として一般に供するための転圧コンクリート舗装技術 基準（案）を今年度中に策定できる見通しである.

このように，技術的課題の検討については順調に推移 しているが，RCCP の実施において現在のところ材料 供給面に問題がないわけではない。これは RCC が超硬 練りコンクリートであるため，生コン工場がその製造に まだ習熟していないことのほか, ミキサーの混練り能力 が公称容量の $70 \%$ 程度に低下することなどが原因と考 えられる.

幸いこの問題については，たとえばセメント協会と全 国生コン工業組合連合会におけるRCCP 用コンクリー ト製造マニュアルの作成などによる対応が進められては いるが，良質な混合物の安定供給に対する RCC 生産者 の一層の努力が望まれる.

また，わが国の RCCP の施工規模についても問題が ある. すなわち 1988 年度までの施工件数の実に $3 / 4$ が $2000 \mathrm{~m}^{2}$ 以下ときわめて小規模であったことも，工事の 採算性を低下させているものと思われるが，今後は試験 的段階を脱却して，施工規模も拡大してゆくよう発注者 に期待したい.

さて RCCP が多くの可能性を秘めた工法であること は間違いないが, 今後, これが各種舗装の中で占める地 位を予測しようとするとき，RCCP を単に，通常のコ ンクリート舗装のコンクリート版をローラ転圧で仕上げ る工法としてとらえるのは適当でないように思われる.

RCCP 工法には，早期交通開放が可能，版厚が自在 に変えられる，小規模工事でも適用しやすいなどの特徴 がある.したがって本工法によれば，たとえば重交通道 路の交差点部などで工事中の交通対策上の理由で，コン クリート舖装の採用を断念していた場所にも，コンク リート舗装の適用が可能になるなど, 従来の舗装工種選 定の考え方を変える必要がある場合さえある.

一方，施工法が異なれば舗装材料も異なるし（これは 逆にいってもよいが), 舗装構成の考え方や，さらには 路面性状が，従来の舗装と同じでなくても少しも差し支 えない。

このような考え方のものとして，たとえば $5 \sim 10 \mathrm{~cm}$ のより薄層の RCCP で, RCC 用骨材の一部にアスファ
ルト舗装の再生骨材を用い, これをセメントミルクと一 括混合し，通常のアスファルト混合物と同じ施工方法を とる混合式半たわみ性舗装 ${ }^{13)}$ ，空隙を大きく確保できる 骨材粒度にした RCC を軽量ローラで転圧する透水性舗 装犃などもある。これらはほんの一例に過ぎないが，既 往の構造, 材料, 施工法にとらわれぬところに, RCCP 工法の適用範囲が拡大していくことも考えられ る.

要は枝葉末節にとらわれることなく，その舗装に要求 される供用性を満足する範囲内で, できる限り経済的に RCCP 工法の特徵を十分に発揮させるという合理的な 考え方のもとに，本工法が広く活用されることを期待し たい.

おわりに，本文の執筆にあたって数多くの文献を参照 させて頂いたことに御礼申し上げるとともに，資料の整 理に協力して下さった坂田耕一, 野田悦郎両氏の労に感 謝の意を表する.

\section{参 考 文 献}

1) ACI Committee $309:$ Recommended Practice for Consolidation of Concrete, Jrnl. Amer. Concrete Insti, Dec. 1971

2) 国府勝郎：転圧コンクリート舗装の現況, 舗装, Vol. 23, No. 4, pp. 4 7, 1989 年 4 月.

3) Anderson, R. : National Report, Sweden, 18 th World Road Congress.

4）（社）セメント協会：RCCP 欧米調查報告書一欧米にお ける RCCP の実態一, 昭和 63 年 3 月.

5）北海道土木技術会舗装研究委員会：北海道舗装史（上).

6）日本道路協会セメントコンクリート舗装小委員会：転圧 コンクリート舗装試験舗装要領 (案), 昭和 63 年 8 月.

7）（社）セメント協会取りまとめ (平成元年 7 月現在).

8）井上武美・尾本志展：転圧コンクリートの疲労, セメン 卜技術年報 42 , pp. 543 546, 昭和 63 年.

9) 中丸 貢・辻井 豪：ローラコンパクテッドコンクリー トの舗装への利用に関する実験, 第 8 回コンクリート工 学年次講演会論文集, pp. 449 452, 1986 年.

10）酒井 脩ほか：転圧コンクリート舗装の施工一山陽自動 車道沼田パーキングエリア一，舗装，Vol.24，No.4, pp. 17〜25, 1989 年 4 月.

11）建設省関東地方建設局関東技術事務所，(社）セメント協 会：昭和 62 年度転圧コンクリート舗装共同開発報告書, 昭和 63 年 3 月.

12）福田 正：コンクリート舗装の荷重分散機能に関する研 究, 土木学会論文集, 第 242 号, pp. 63 72, 1975 年 10 月.

13）坂田耕一ほか：転圧タイプの半剛性舗装の基本性状と供 用性, 第 17 回日本道路会議一般論文集, pp. 446 447, 昭和 62 年.

14）花園駿一郎ほか：本庄郵便局操車場における透水性コン クリート舖装, 道路とコンクリート, No. 66, pp. $27 \sim 33$, 1984 年 12 月.

（1989.7.8 • 受付） 